\section{(2) OPEN ACCESS}

\title{
How care holds humanity: the myth of Cura and theories of care
}

\author{
Halvor Hanisch
}

\begin{abstract}
Correspondence to Dr Halvor Hanisch, Work Research Institute, Oslo Metropolitan University Centre for Welfare and Labour Research, Oslo, Norway; hamha@oslomet.no
\end{abstract}

Accepted 5 August 2021

Check for updates

(c) Author(s) (or their employer(s)) 2021. Re-use permitted under CC BY-NC. No commercial re-use. See rights and permissions. Published by BMJ.

To cite: Hanisch $\mathrm{H}$. Med Humanit Epub ahead of print: [please include Day Month Year]. doi:10.1136/ medhum-2020-012136

\begin{abstract}
Modern medicine has often struggled to grasp the cultural aspects of interpersonal care. The medical humanities, on the other hand, have struggled to grasp the embodied, intimate character of care. In a recent appeal to the medical humanities, Julia Kristeva et al argue that care can be a point of crossing between these two 'ontological domains'. They evoke the myth of Cura, referring to previous utilisations by such diverse thinkers as Heidegger and Kleinman, as well as Kristeva's previous work. This study adds to these bodies of work by using the original text from Hyginus in much greater detail. Textual analysis, theoretical discussions and autotheoretical work unpack care as (1) a fundamental aspect of the human condition, (2) a holding-together of different domains of knowledge, (3) a withholding from these domains and (4) the site of intimate knowledge that both 'ontological domains' struggle to grasp.
\end{abstract}

\section{INTRODUCTION}

The subject of care is gaining importance within the medical humanities, but it also remains elusive. Hence, this paper aims to unpack theoretical notions of care in a way that integrates the elusiveness rather than trying to avoid it. It also responds to a recent article by Julia Kristeva et al, in which they claim that care holds humanity (Kristeva et al. 2018).

When in need of theoretical elaboration or re-development, medical humanities scholars have sometimes evoked Greek or Roman myths, such as those of Narcissus, Hephaestus or Leto (Cilione, Marinozzi, and Gazzaniga 2019; Pannese 2011; Schott 2017). Similarly, this article evokes the Roman myth of Cura to unpack theoretical understandings of care. In this myth, known from the writings of the first century mythographer Hyginus, humanity is created from clay by a personification of care. It has proven useful to thinkers as diverse as Martin Heidegger, Arthur Kleinman (Kleinman and van der Geest 2009) and Julia Kristeva (Kristeva (2012), Kristeva et al. 2018). While utilisation by Heidegger 1927, 196-200 'challenges the myth of self-sufficiency and individual atomization that that has shaped much of modern Western philosophy' (Froese 2005, 16), both Kleinman and Kristeva explore the tension between universalised knowledge and the singularity of individual patients and intimate care (Engebretsen, Fraas Henrichsen, and Ødemark 2020).

While none of these scholars engage with Hyginus' Fabulae directly, I use the text as an 'engine' in a four-step endeavour. This endeavour follows Brandy Schillace's description of the medical humanities as 'a field that at its core considers the human story behind and within medicine, its history, its cultural valence and its influence on practice' Schillace $(2017,139)$.

First, a 'human story' entails agency, the things that humans do in their lives. While the 'appeal' from Kristeva et al uses a case from intercultural psychoanalysis, the authors have previously researched a variety of professional healthcare practices (Engebretsen 2016; Engebretsen, Sandset, and Ødemark 2017; Hetrick et al. 2017). However, it is crucial to note that Cura (in Hyginus' text) will 'hold' humanity quamdiu vixerit (for as long as he shall live). Such a life-long temporality does not dovetail with the temporary, regulated and systematised relations of healthcare organisations. Hyginus' text has, I argue, a much stronger affinity to the temporality of parental care. Hence, I begin the endeavour by acknowledging that I am a scholar, and the father of a boy with little linguistic function. ${ }^{1}$ Although my parental care for my son entails a multitude of meanings and instances, I begin with two tales from my parental care in 2020:

\section{Sometimes, if he does not understand what is going on, or if his actions feel unintelligible to others who are present, I take him in my arms. In that way, we are at least together in a situation when both of us other- wise would have been on our own. Suddenly, it feels as if I am not only holding or embracing him away from an abyss. I am also holding him-or, perhaps, shielding him -in the face of many, many abysses to come. \\ In rough-and-tumble play, I often lift him up with my arms straight-holding him while he straightens his body, and 'is an airplane'. Although this play is ex- hausting, particularly since I live with cerebral palsy, this is nevertheless an activity where we can be close to one another. When I hold him up like this, or suddenly 'crash' him safely down next to me on the bed, we are skin to skin, but not exactly like I used to be with his older siblings, and I suddenly have the impression that it also differs from how most fathers do this with their children. I cannot know if our way is exclusively ours, but while I hold him, that is how it feels.}

Second, a human story 'behind and within medicine'-or, for that matter, behind and within any social field-consists of underlying notions and involved cultural categories. Hence, this article aims to unpack theoretical notions of care with reference to the thinkers mentioned above. Throughout, I try to unpack how different aspects of care 'follow' each other in an analytical 'path' or trajectory, as if in a story (Kristeva et al. 2018).

Third, the investigation of the human story of care must become an investigation of 'history' and 
'cultural valence'. In order to think historically, the analytical 'engine' includes Hyginus' text, and 18th and 19th century uses of Cura and related motifs.

Fourth, I follow Schillace's advice to examine 'influence on practice'. In addition to the practice of parental care, the exploration ends with a discussion of medical humanities as practice. When medical humanities scholars 'consider' the human story of care, they bring together different perspectives and forms of knowledge. In this case, however both the intertextual analyses and the autotheoretical work indicate that those complexities might overpower our theoretical perspectives. Hence, I conclude with a call for epistemological and analytical modesty.

\section{METHOD}

Although the abovementioned scholars have used the myth of Cura for clearly theoretical purposes, several of them explore this also as carers in a personal sense: Julia Kristeva writes her work on care as the mother of a man with severe disabilities Kristeva (2013, 219-221), Arthur Kleinman and Geest (2009, 159-163) begin their rethinking with a rich narrative of his caring for his wife who lives with Alzheimer's disease. In line with their work, this article combines textual interpretation with autotheoretical work.

Often used in connection with genre-bending memoir The Argonauts by Maggie Nelson (2015), the term 'autotheory' designates a literary form involving 'the combination of autobiography and critical theory' (Pearl 2018, 200). In this article, however, I rely on the work of the Canadian artist, curator, writer and interdisciplinary researcher Fournier (2019), who has unpacked autotheory with particular reference to illness and embodiment. Fournier describes autotheory as a specific form of academic practice:

In autotheory as a conceptual and performative feminist practice, artists, writers, and critics use the first person, or related practices of self-imaging (Jones, Self/Image 134), to process, perform, enact, iterate, and wrestle with the hegemonic discourses of 'theory' and philosophy, extending the feminist practice of theorizing from one's subject positioning as a way of engendering insights into questions related to aesthetics, politics, ethics, and social and cultural theory. In autotheory, one's embodied experiences become the material through which one theorizes, and, in a similar way, theory becomes the discourse through which one's lived experience is refracted (658).

In Fournier's definition, theory functions as 'hegemonic discourses', and as discourses through which one's lived experience is refracted. Contrary to this emphasis on language-as well as their emphasis on language elsewhere (Heidegger 1927Heidegger 1937; Kleinman 1995; Kristeva 2019)—neither Kristeva nor Kleinman or Heidegger focus on Hyginus' text. In contrast to this body of research, this article emphasizes the interpretative potential of the original text. In addition to grammatical analysis, I utilize the well-known concept of intertextuality, as introduced by Kristeva (1980). However, I use it in a less structuralist sense than in her early formulations in Desire in Language. Instead, I approach Hyginus' text in line with her approach in 'Nos Deux' or a short (hi)story of intertextuality (Kristeva 2002).

For me, intertextuality is mostly a way of making history go down in us. We, two texts, two destinies, two psyches. It is a way if introducing history to structuralism and its orphan, lonely texts and readings. [...] the etymological meaning of 'semeion' is a distinctive mark, a trace, an engraved or written sign, that makes us think of the Freudian 'psychical' marks, called drives, rhythmical articulations of embodied impulses and psychical movements. In this sense, the meaning of the socio-historical aspect of intertextuality, as already developed by Bakhtin and Barthes, acquires a new significance: within each sociolect or ideology, (both well-established sign-systems) there will always be a breach of subjectivity carrying out a hidden matrix of pre-symbolic forces able to make history move on through all its short and singular stories. (2002: 8-9)

First, this means that I study Hyginus' text not as a 'lonely text', but as part of a historical trajectory. The 'singular stories' are used to disturb the orderly (structural) notions of both textual and philosophical analysis.

Second, I interpret Hyginus' text-as well as other utilisations of the myth-with focus on traces. Or, more specifically, to find 'distinctive marks' relevant to the same material as in authotheretical work: 'embodied impulses and psychical movements'. This, however, does not mean that the texts are reduced to a canvas for an engraved sign. In methodological term, the aim is to allow the two destinies- the textual trajectory of the Cura motif, and the personal trajectory that becomes so intimate when I hold my son in my arms-to shed light on one another.

Third, the interaction between these two methodological approaches will hopefully allow history-what Schillace calls the 'human story'-to move in two diachronic ways. I aim to emphasise the differences between the different utilisations of the myth. Finally, I also aim to locate breaches in the 'wellestablished sign systems' we call theories of care, to get a glimpse of something yet hidden.

\section{HUMANITY AS CREATION, CARE AS FUNDAMENTAL CONDITION}

In a narrative sense, Hyginus tells three stories: a story of the creation of humanity followed by a story of a quarrel between deities and finally, a verdict on the ontological role of care in human life. The first story in Hyginus' fable begins thus:

Cura cum quendam fluvium transiret, vidit cretosum lutum; sustulit cogitabunda et coepit fingere hominem.

When Cura was crossing a certain river, she saw some clayey mud. She took it up thoughtfully and began to fashion a man.

Before interpreting this first story, we must first acknowledge that the fable is an alteration or addition in a philological sense. While Fabulae is almost exclusively filled with Greek myths, the Cura fable's position at the end of the collection suggests, 'that this particularly Roman tale was simply added to the end of the existing narrative portion' (Smith and Trzaskoma 2007, xlix). Moreover, philological research consistently argues that fable CCXX 'hinges on Latin wordplay' (Smith and Trzaskoma 2007, xlviii).

More specifically, Hyginus, in the Cura fable, alters a prevailing myth in late antiquity, one that he has even told earlier in the pages of Fabulae: that of how the titan Prometheus fashioned man from clay. In fable CXLII ('Pandora'), Hyginus states explicitly that Prometheus lapeti filius primus homines ex luto finxit (Prometheus, son of Iapetus, first fashioned men from clay).

Most Greek and Roman sources place the Prometheus plasticator motif within a three-stage narrative: first, Prometheus shapes the human from clay, and then Athena gives the creature inner life. Finally, sometimes after Prometheus has given humankind fire against the orders of Jove, Jove intervenes and sentences Prometheus to eternal punishment in the Caucasus.

To understand the human story-to which both this motif and Hyginus' text belong-comparison is needed. First, we must note that the neutral or slightly idyllic depictions in Hyginus and Ovid (respectively) differ from earlier and less optimistic renderings in Republican times. The poet Propertius, for instance, in 
his Libri Elegiarum from the first-century BC, laments and elaborates on how Prometheus was careless in his creating. Here, the adverbial clause ille parum caute casts Prometheus as a figure of titanic heedlessness:

\section{ille parum caute pectoris egit opus.}

corpora disponens mentem non vidit in arto:

The making of man's reason he performed with too little care.

Arranging our bodies, he overlooked the mind in his handiwork (Goold 1990, 232).

Carelessness, the counterpart to the notion of care, is involved in the Prometheus plasticator motif throughout antiquity. The adverbial clause ille parum caute does not derive from the same verb as Cura, but rather from the verb caveo (to take precautions, to be aware of something). Nevertheless, Prometheus' lack of care underlines how Hyginus' text is an inversion these earlier texts: instead of being created in a careless way, humanity is created by care.

To be fair, a singular text never exhausts the potential of the history to which it belongs. Specific understandings-in this case: theoretical notions of care-are only a part of a wide array of potentials. The Prometheus Plasticator motif foreshadows 20th and 21 st century theories of care, and 18th and 19th century depictions of Prometheus as a figure of romantic transgression. In Goethe's poem Promethevs (written 1774, published 1789), Prometheus becomes a figure of independence and defiance-as expressed, for instance, in the final stanza:

Hier sitz' ich, forme Menschen / Nach meinem Bilde, / Ein Geschlecht, das mir gleich sei, / Zu leiden, zu weinen, / Zu genießen und zu freuen sich, / Und dein nicht zu achten, / Wie ich!

(Goethe 1998, 44-46)

Here sit I, forming mortals /In my image; / A race resembling me, / To suffer, to weep, / To enjoy, to be glad, / And thee to scorn, /As I! (Bowring 2015, 182)

Typical of Goethe's Sturm und Drang period, his Prometheus Plasticator is a figure of creativity, and embodies 'ideals of freedom and rebellion' (Raggio 1958, 44). Goethe's poem emphasised the 'autonomous existence' of mankind (Dougherty $2006,95)$, thereby constituting an 'emancipatory gesture' (Edgar 2002, 161). Hyginus' text inverts both classical and romantic evokings of the myth by inserting dependency rather than autonomy and expansion. To shed further light on this inversion, we must first unpack the name of the personification that Hyginus instals in the Prometheus Plasticator motif: Cura.

The name Cura is derived from the verb curo. The Oxford Latin Dictionary defines the verb thus:

1. To watch over, look after, care for.

2. To tend to, to do what is necessary to.

3 . To administer remedies, to treat (a sick person, wound, disease, etc).

4. To have charge of; (absol.) to be in command.

5. To devote oneself to, to cultivate (a person).

6. To undertake, to see to (a task or a responsibility).

7. To regard with anxiety or interest, worry or care about, heed.

As we can see, the first three senses of this verb invert the Prometheus motif we found in Propertius: to instal the personification of curo in the motif is to instal carefulness, attentiveness and responsibility in a motif usually filled with lack of care. The third sense also injects an aspect that is totally absent in classical anthropogenies: that of human frailty. It also relates to aspects of human lives that are particularly relevant to understanding care, illness, disease and disability.
The fifth and sixth senses of the word similarly invert the romantic depictions of Prometheus motif: the anthropogenic act is no longer about rebellion and expansion, but devotion and responsibility. The seventh sense finally reverses the political impulse of the Sturm und Drang-the desire for increased individual freedom and self-expansion in every imaginable wayinto worrying and heeding.

In addition to these intertextual relations, it is also fruitful to note the verbs that connect humanity to the three deities. While Cura's creating is described with the verb fingo (in Hyginus: 'fingere'), Jove's and Tellus' acts of giving are described by do (in Hyginus: 'dedisti'). While the former verb is a very tactile verb, a matter of touch and contact, do signifies separationto deliver or give something, to separate it from something in order to unite it with something else. An initial understanding of care emerges from these textual relations: care is fundamental (by belonging to the anthropogony), antithetical (by being the antithesis of carelessness and neglect) and intimate (by establishing relation through touch).

\section{CARE IMAGINATIONS}

When modern scholars use Hyginus' text, one word of the first sentence is often overlooked: cogitabunda (thoughtful). Although an adjective in the purely grammatical sense, this is the only word with an adverbial function in Hyginus' text. Hence, it is the lone term specifying how actions and interactions take place. While Greco-Roman deities often act from rage (as in the conflict between the titans and Olympian deities) or desire (as in the story of Zeus and Leda), Cura acts thoughtfully or with thought.

As we can see, the adverb cogitabunda is attached to the picking up of the clay, not primarily to the act of creation: sustulit cogitabunda et coepit fingere hominem. Moreover, the temporal clause 'and begun to' (et coepit) also locates this thought as prior to the creation of humanity. To understand care as thoughtful, then, is about understanding thoughts and imaginaries 'involved' in care, and it includes thoughts and imaginaries that 'pre-exist', 'frame' or 'underpin' care and care work.

It is useful to explore how the meaning of cogitabunda is preserved and unveiled in the work of the German philosopher, poet and literary critic Johann Gottfried Herder (1744-1803). In his poem 'Das Kind der Sorge' (1787), Herder follows Hyginus very closely (Bernays 1869, 158-163). This poem was widely read, and it provided the basis for Goethe's use of the Cura motif in Faust II (1832). Finally, Heidegger also comments on the poem and cites it in extenso when he develops his notion of Sorge as the fundamental human condition (Dye 2009, 207-218)., Kristeva (2001), too, refers several times to Herder, and even refers directly to this poem $(25-26)$. The first stanza describes the moment of creation thus:

Einst saß am murmelnden Strome

Die Sorge nieder und sann:

Da bildet im Traum der Gedanken

Ihr Finger ein leimernes Bild (von Herder 1889, 75).

Once by a murmuring river

Sorrow sat down, and there,

In a vision, thought to form with the touch

A wavering figure (Groth 2016,31).

von Herder positions the moment of creation as a radically imaginative act in at least three ways. First, the gaze is far more manifest in von Herder's text than in Hyginus'. While Hyginus' Cura shapes a human (bominen) directly, von Herder's 'Sorge' 
shapes an image $($ Bild). This dovetails well with important insights from care research. In relations of care, the cared-for becomes visible to the carer(s), thereby also becoming a valued imago. Conversely, the carer(s) become visible in the imagination of the cared-for-even in a Western culture that often obscures or silences interpersonal interdependence.

Second, cogitabunda in Hyginus is also intertextually connected von Herder's adverbial clause im Traum der Gedanken. This phrase, roughly translatable as 'in the dream of thoughts', roots humanity in a singular image (or dream) that consist of or belong to several different thoughts or ways of thinking. This tension between individuality and multitude dovetails with research on the knowledge complexities involved in care.

Third, the word 'Traum' (dream) in Traum der Gedanken does not denote unreality, fantasy or illusion. For von Herder, dreams are not the opposite of reality, but thoughts beyond or above manifest reality (Wirklichkeit überhöhenden Gedankens). A dream of thoughts, then, is an experience or interpretation wherein the understanding of a phenomenon moves beyond how the phenomenon presently is, to what it should or could be. Just as Hyginus' cogitabunda can, if we interpret in intertextual connection with von Herder's Traum der Gedanken, also refract my experiences of holding my son in my arms. This is true of the experiences of performing actions that seem strange or unintelligible to those around us, but particularly true of the feeling of doing this in a way that is uniquely ours. The combination of these feelings-where the socially estranged ways of caring is fundamentally ours and integral to my parenting-engenders or entails a striving 'upwards'. This striving is not limited to the idealisation that so often takes place in parenting, but is also a utopian, imaginative glimpse of a world wherein the both of us truly belong.

In other words, the Cura motif foreshadows the 'horizontal' complexities involved in care (multiple cultural imaginaries, multiple forms of knowledge). It also foreshadows 'vertical' complexities, through which care imaginations include both underlying categories and überhöhende dimensions. These overarching or utopical dimensions, that both stem from and go beyond the localised, singular imaginations of care, is known by many names in and beyond the medical humanities. Examples include 'underlying values', 'ethical content of particular practices', 'transformative learning' and many others (Ayala 2019, 269; Pettersen 2008, 188; Winthrop 2003).

Cogitabunda, can mean to be thoughtful and to be 'full of thoughts'. The adverbial clause im Traum der Gedanken by von Herder $(1888,533)$, similarly, also signifies something unclear or disorganised. In his poetotological treatise Über Bild, Dictung und Fabel $(1888,533)$, von Herder juxtaposes this state with being in Leidenschaft (in passion), in Verrückung (in madness) or nicht auf seiner Hut (off guard). There is complexity and openness-perhaps even fantasy or at least exploration-in this. When I hold my son in my arms connecting different realms of thought. As in ruff-and-tumble-play, these realms are also at play as I think.

\section{THE QUARREL OF THE DEITIES: CULTURE, NATURE AND CARE}

After the first narrative, the second deals with a quarrel between the deities Cura, Jove and Tellus. Once humanity has been given inner life, the focus in Hyginus' texts shifts from creating to name-giving:

Cum vellet Cura nomen suum imponere, Iovis prohibuit suumque nomen ei dandum esse dixit. dum de nomine Cura et lovis discep- tarent, surrexit et Tellus suumque nomen ei imponi debere dicebat, quandoquidem corpus suum praebuisset.

When Cura wanted to give it her name, Jove forbade, and said that his name should be given it. But while they were disputing about the name, Tellus arose and said that it should have her name, since she had given her own body.

To name something after something else (and, perhaps particularly, after someone else) places the object within a certain taxonomy. Major deities such as Jove and Tellus are both rulers and personifications of different ontological realms or 'elements'. Hyginus' Cura is not known from other Roman sources; instead, Cura is a 'deification of abstract ideas', a common feature of Roman culture (Axtell 1907). Hence, it becomes clear that the quarrel deals with ontological ideas, more specifically with the ontology of humanity: each deity proposes a 'location' in classical ontology.

The philosopher John T. Hamilton has used the myth of Cura to explore how any understanding of security presupposes both care and carefulness. He underlines how this 'locating' somehow names humanity after something that is neither identical nor particularly resembling humanity:

The controversy over the creature's name strives to resolve the issue of the figure's proper being, without the aid of physical resemblance, without the talent for self-reflection. In my view, the debate over the name revolves on whether humanity is essentially atemporal (Telluric matter or Iovian spirit) or instead fundamentally temporal and constituted by time and history (Hamilton 2013, 71).

It is worth noting that the deities are not offering or suggesting certain framings of human life. Hyginus' text-in particular, the fact that Jove forbade any name other than his own-indicates conflicts between perspectives and disciplines. The imaginative richness involved in care, indicated by Hyginus cogitabunda or by the plural in von Herder's Traum der Gedanken, is a plurality where incommensurabilities remain. In my view, the myth of Cura points towards three possible but incommensurable ways of studying, describing and interpreting care (corresponding to Jove, Tellus and Cura, respectively):

- As a cultural or semantic phenomenon, elucidated in terms of meaning or more or less idealised notions.

- As a biological phenomenon, elucidated in medical, psychological or other health-related terms.

- As a relational phenomenon, elucidated in terms of care work (professional or not).

Although it is necessary to understand care in all these ways, it is nevertheless impossible to fully merge them or produce those understandings simultaneously. Hence, it is necessary to add a more epistemologically oriented aspect of care: care is fundamentally imaginative and context-dependent, and stands in-between otherwise incommensurable interpretative domains.

\section{SATURN'S VERDICT: THE CONTINUOUS PRESENCE OF CARE}

In the third narrative in Hyginus, the quarrel is somehow resolved when the deities choose Saturn as their judge. Sadly, this part of the text is fragmented. There is agreement, however, that Saturn's verdict clarifies that Jove will receive human souls, while Tellus will receive the body post mortem:

Tu Iovis quoniam spiritum dedisti, $<\ldots>$ corpus recipito. Cura quoniam prima eum finxit, quamdiu vixerit, cura eum possideat; sed quoniam de nomine eius controversia est, homo vocetur quoniam ex humo videtur esse factus

Jove, since you gave him spirit, let [Tellus] receive his body. Since Cura fashioned him from the start, let Cura possess him for as long 
as he lives; but since there is controversy about his name, let him be called homo, since he seems to be made from humus.

Let us begin by pointing out that Saturn's verdict exposes yet another way in which Hyginus' text alters the Prometheus plasticator motif. In most classical renderings, Prometheus is a trickster, and a transgressor from whom humanity is eventually separated. After discovering his transgressions, the Olympian deities chain Prometheus to a mountain in the Caucasus, and humanity lives on without him. The relation between humanity and its creator is therefore temporary. Hyginus, in contrast, makes it clear that humanity will remain under the guardianship of Cura quamdiu vixerit 'for as long as he shall live'.

The significance of this difference becomes clearer if we compare Hyginus' text to Ovid's use of the Prometheus plasticator motif in Metamorphoses. After describing the original moment when Prometheus created Humanity, Ovid goes on to describe the human condition:

quam satus Iapeto mixtam pluvialibus undis / finxit in effigiem moderantum cuncta deorum, / pronaque cum spectent animalia cetera terram, / os homini sublime dedit caelumque videre

(Ovid 1997, 47)

so that his new creation, upright man, / was made in image of commanding gods? / On earth the brute creation bends its gaze, / but man was given a lofty countenance / and was commanded to behold the skies; / and with an upright face may view the stars (Melville and Kenney 2009, 76).

As we can see, Ovid's Prometheus creates a strong and vital human being. Humanity seems not dependent on care or assistance, but 'made in image of commanding gods'. In Ovid, human life is essentially an independent life which resembles the lives of gods (in effigiem moderantum cuncta deorum). It is commonand tempting - to imagine care relations as exceptions in human lives. In care research, for instance, one often reserves care needs for vulnerable groups, thereby contrasting them with some kind of original, non-vulnerable state. In life-course research, similarly, care leaves life as people move into adolescence and adulthood, only to re-enter it in the special cases of disability, serious illness or old age. Hyginus' text, in contrast, opens up for a rethinking of care as a fundamental, continuous part of human lives.

This is essentially an ontological argument: although we often reserve the term for human beings who have unusual needs-for instance, children or people with disabilities-care is, in fact, much more pervasive.

Noting the etymology of the verb curo-denoting what we call caring and worrying-Hyginus' text also points towards an understanding of care as protection. The notion of care becomes meaningful in and of itself, and in relation to its counterparts, such as conflict, violence and neglect. If the so-called 'normal' human life-in Ovid's words: lives lived 'in the image of commanding gods'-is met by a radical lack of care, it would have little freedom and in fact be over in a matter of days.

Hyginus' text points towards an understanding wherein care reigns, organises or facilitates human lives: Cura somehow 'holds' humanity in this life, indicating that Jove's and Tellus' receiving somehow lies outside that life (after death). For the medical humanities, this understanding of care suggests ways to think about both medical and cultural knowledge as forms of afterlife. Biological knowledge, for instance, is a form of knowledge that has been aggregated outside and beyond individual lives: through clinical generalisations, anatomical knowledge, systematic literature reviews and more. Cultural knowledge, conversely, is deeply historical and contextual-thereby inevitably also a testament to how both historical and contextual relations stretch far beyond individual lives.

These ambiguities lead to a further understanding of care: care is not only a fundamental precondition-whose impact depends on context and interpretation-care is indeed a fundamental and omnipresent condition, that continuously engenders and relies on interpretative processes.

\section{CARE AS HOLDING-TOGETHER}

When I hold my son I ruff-and-tumble play, I am also holding together forms of knowledge. I connect many different forms of knowledge-my intimate experiences with him, my research experience from disability studies, the bits of knowledge I have received from medical and educational professionals and many others-with one another. Moreover, the knowledge I produce-from the actual holding, from being skin to skin and from sensing if he cannot understand others-is used in knowledge translation: I use it to stretch the understandings of medical professionals beyond uncertain prognoses. I also use it to connect the knowledge of the preschool teachers-a knowledge which mainly deals with so-called ordinary children-with the lives of extraordinary children such as my son.

In Hyginus' text, too, Cura holds together what otherwise would have been separate: Had it not been for Cura's holding, and Saturn's verdict, humanity would have belonged to either Jove or Tellus. A recent 'appeal to the medical humanities' uses the potential of this narrative. In it, Kristeva et al. (2018) use the myth of Cura to explore how humanity 'belongs to different ontological domains' held together by care:

Saturn, the God of time, settles the matter through an act of naming and by dividing and temporalising the possession of the various parts that comprise man: Jove is offered man's soul and Tellus his body, after man's death, while Cura will possess the creation in its lifetime since she made it. [...] Thus, human life as a composite assembly of spiritual (Jove) and material elements (Tellus) is held together by Cura's temporal care (55).

In their unpacking, Cura's holding of humanity becomes a holding-together of two forms of knowledge: biomedical knowledge of bios and sociocultural knowledge of zoe. Faced with situations of care-situations that neither biomedical science nor cultural studies of health can understand sufficiently-the understanding of care becomes a point of intersection between otherwise separate landscapes.

This holding-together is visible in a variety of care practices. In the case of evidence-based care, for instance, temporal doing at a certain point in time and history (professional work) holds together atemporal knowledge of effects (evidence) and atemporal norms (professional ethics). The temporal care work may seem like a mere 'application' of these atemporal knowledges. However, recent studies argue that both evidence and norms exist as such if and only if they are interwoven with embodied practices. While 'evidence in clinical decision making is relentlessly situated and contextual' (Wieringa et al. 2017, 964), so can the normative aspects only be sufficiently understood as 'embodied process', located at 'the action level' (Doane and Varcoe 2008).

Jove, Tellus and Cura personify ontological orders (ways of being), and epistemological orders (ways of knowing). If we then revisit the epistemological aspect of care, a further understanding emerges: care is a relational matter-in the lived lives of care receivers, as well as in the work of care professionals-and it is 
crucial in holding together different social agents and different knowledge domains.

\section{CARE AS WITHHOLDING}

When I 'play airplane' with my son-or hold him close to me in situations where others do not understand him or vice versaone might say that I know what I am doing. On the other hand, this holding challenges several parts of my knowledge of this world. It challenges my images of what it is to be a father, since the play differs from how most fathers do this with their children. More importantly, perhaps, the knowledge produced when I hold my son in my arms in the face of many, many abysses to come differs from much of my academic and medical knowledge, including that which is inherent in his diagnoses and prognoses.

This withholding might seem, contrary to the straightforward clarity of Hyginus' text. However, a more detailed examination can refract these interpretations. It is particularly worth noting that the relation between Cura and the human being-that is, the fundamental ontological condition in this life-is described with a specific verbal clause with the verb possideo: cura eum possideat (Cura shall hold him).

The Oxford Latin Dictionary defines possideo thusly:

1. To have (land) in one's control, occupy (as a tenant, etc); (absol.) to hold land.

2. (in general) to hold as property, b. to take (property) into one's keeping, appropriate.

3. (of a sovereign, army, etc) to have control of (a country, position, etc) [...] to assume or exercise control over (persons).

4. To take or have in its power, dominate, overwhelm, possess.

5. To fill or take up (a space) with one's bulk.

6. To take up wholly (a person's time); to absorb the thoughts and energies of someone.

Possideo denotes not a general sense of holding, or a more general sense of contact or connection, but an exclusive holding-similar to the English verb to possess. Cura, then, is not only holding a humanity that belongs to both Jove and Tellus, but she is also withholding this humanity from them. This becomes even clearer if we emphasise that possideo is a transitive verb. At least to some extent, the clauses quamdiu vixerit, Cura eum possideat entail a micro-narrative: Although 'created from,' or consisting of biological matter, and being characterised by the presence of 'soul' or some measure of cognition, humanity is fundamentally 'controlled' by care in this life. The separating into meaning (spirit) and biology (bodily remains) takes place outside this life. Cura's holding, then, allows us to understand the holding-together of medicine and culture, and a withholding from both these domains.

The 'hermeneutic story' (Kristeva 2002, 10) of Hyginus' possideat-wherein care holds humanity at the expense of both culture and biomedicine-contradicts epistemological optimism: Hyginus text allows us to glimpse intimate care knowledge that connects cultural and biomedical knowledge, and that holds human life away from generalised knowledge. When Cura withholds humanity from generalised cultural knowledge (Jove) and generalised biochemical knowledge (Tellus) and care produces knowing-often described as insight, sharing and holdingtogether-and un-knowing.

These difficulties indicate the need for an additional understanding of care: care must be understood as a practice that holds together multiple parties and multiple forms of knowledge. However, it must also be understood as a practice-or if you will: a form of human relation-that withholds something from knowledge.

\section{SHALL HOLD HIM FOR AS LONG AS I SHALL LIVE}

The 'human story' of care relations (eum possideat) will necessarily entail a human story of singular actions that to some extent can only be described in first-person singular: eum possideam (I shall hold him). To explore this individual eum possideam, I try to 'theorise from my subject position' (Fournier 2019, 658). When activating my own intimate experiences, it became clear that interpretations of my eum possideam quamdiu vixerit can refract-or even fracture-theoretical notions of care.

To connect intimate experiences of holding-be it in bodily care, in adverse social situations or in rough-and-tumble playwith cultural and political theory is clearly a daunting task. Although this still seems unclear to me, I can at least outline four aspects of the refraction. First, I do hold together cultural and biomedical knowledge: when my son is in my arms, multiple cultural imaginaries are involved. My understanding of his life (and of mine) is dependent on my language and my cultural frames, and I am consistently aware of a clinical gaze: my son's life-and, thereby, also my own life and my care work-are viewed or observed by medical professionals, psychologists, special needs educators and preschool teachers.

Second, the holding is troublesome. In a narrower sense, I note that his needs lead me to hold and even carry him in ways that most parents only do with substantially younger children. Combined with my own embodied condition, there emerges a bodily trouble, an element of exhaustion, uncertain walking and muscular pain. Regarding my cultural knowledge, it becomes clear that my own imaginaries entail expectations and understandings that somehow seem incompatible with his life. In this social context-parenting in Norway, located in middle-class families—childhood is simultaneously about 'findings one's own voice' (autonomy) and about 'following the path' (social reproduction). To claim that autonomy outside language is possible, or that a person in his situation may reproduce his parents, seems equally futile.

Regarding biomedical knowledge, I take care of my 4-year-old (as I do all three of my children) within a biomedical framework: most Norwegian children are screened regularly for somatic problems, and to measure linguistic, cognitive and psychosocial development. While this knowledge has thus far granted me a certain comfort in parenting my two oldest children-confirming, as it were, that all is well-that has, obviously, not been the case with my youngest son. Hence, his life is also framed by medical knowledge in a more direct way; he receives a range of health-related services, a provision that also positions my parental care within the same frame.

Third, there is an uncertain future involved in this. This is of course always true of any intersubjective relation in general and of care relations in particular: the future is open, and it can entail painful events. However, his situation exposes uncertainty in a more radical way. Culturally, it exposes how I see my other children-as having quite stable chances for social reproductionpartly thanks to how I see him: through a fatherly lens of rather unclear hopes and worries. Medically, the tests of my youngest son continuously yield inconclusive results. This has replaced my former sense of parental comfort with gnawing anxiety over his future. Moreover, the complexities of his living leaves me, as a caregiver, with the unpredictability of his diagnostic results, rather than with stable prognoses.

Fourth, these intimate situations entail a particular life-course temporality, which differs from the temporality of professional care, as well from the temporality in Hyginus' text. In the case of professional careers, their work is regulated to certain hours 
(of paid work), and to certain phases of life: most professional carers will retire, and many will pursue other forms of work at some point in time. In Cura's case, her care work is also time limited. The temporality of the deity's existence is sufficient to encompass the temporality of humanity. In both cases, the life course temporality of the carer is sufficient for the imagined care work.

In my parental care work, however, the temporality is insufficient rather than sufficient: in all likelihood, I will somehow care for my son for as long as I am alive. Moreover, this lifelong work will likely be insufficient in at least two ways related to the temporality of $m y$ life: my own ageing will likely reduce my ability to perform the care work, and I will likely die before my son, leaving him without parental care. Hence, the temporality of my care cannot be formulated as eum possideam quamdiu vixerit (I shall hold him for as long as he shall live), but as eum possideam quamdiu vixero (I shall hold him for as long as I shall live).

This rudimentary autotheoretical investigation brings to light three forms of withholding. First, the nature of the holding (eum possideam) withholds care from the epistemological domains that the medical humanities traditionally investigate. Second, the temporality involved in parental care (quamdiu vixero) withholds something from the temporality of professional care. Third, something is also withheld from the 'parental temporality.'. The need care depends on his life (quamidiu vixerit), not on mine. Several forms of knowledge, and several forms of embodied holding, are involved without being fully commensurable. Since I cannot resolve these enigmatic forms of withholding, the theoretical understandings remain breached, implicitly pointing towards not-yet-explicable or not-yetnameable understandings.

\section{WITHHOLDING AND AMBIGUITY}

My holding of my son in my arms come with several temptations. One of them-in particular, as I am holding him, or, perhaps, shielding him-is to think that I hold some kind of vast, privileged knowledge. While this is of course true to some extent, there are more powerful movements at play. On the one hand, the complexities in the situation forces me out of the internal comfort that characterises the centre of any ontological or epistemological 'domain'. On the other hand, I am also forced to admit another thing: that I can hold him, but it remains unclear-to some extent-if I can know him: I cannot know if our way is exclusively ours.

Similarly, intertextual analysis locates breaches in specific 'sign-systems', and in larger 'social and historical material' (Kristeva 2002, 9-10). Hence, the specific inquiries presented in this article relate to more general ways of inquiry: when we use those notions, we connect different academic investigations, and different academic disciplines, theoretical traditions and research methodologies. In Julia Kristeva's words, these relations are 'temporal connections' and 'points of contact' (2002:8) and points of 'distortion, ambiguity and contradiction' (2002:11).

The understanding of care as holding-together connects very well with the rise in interdisciplinarity within the medical humanities. The three deities Jove, Tellus and Cura are brought together in dispute, and Saturn's verdict foreshadows how different ontological domains are held together in human life.

Studying an interaction between form of knowledge-in their case: the interaction between medical imagining and patient creativity-Stahl and Stahl use the insufficiencies of medical knowledge in an argument for multiple perspectives:
Although in contemporary Western society, many tend to believe the hard science provide the truest or most accurate interpretation of the natural world, it cannot exhaust the meaning of the body. If we believe we are more than the sum of our parts, then we ought to allow for multiple and even varied interpretations of our bodies (Stahl and Stahl 2016, 159).

Interpreting care as connectedness and holding-together, medical humanities scholars aim to hold together medical and cultural knowledge in new, explorative and enriching ways, and they often succeed.

Such interpretations also speak to an even more radical ambition, that of academic convergence, sometimes referred to as transdisciplinary research. Such appeals are often embedded in a considerable epistemological ambition. Pointing out the insufficiencies of 'illustrative' or 'additive' work in the medical humanities, Kristeva et al. (2018) express a particularly radical version of this ambition:

[W] do not consider the humanities as a critical and potentially liberating perspective that can be applied to medicine as an object in need of repairment. Medical humanities should not be construed as a humanistic perspective on medicine. They should rather be seen as a cross-disciplinary and cross-cultural space for a bidirectional critical interrogation of both biomedicine (simplistic reductions of life to biology) and the humanities (simplistic reductions of suffering and health injustice to cultural relativism). On the one hand, this implies breaking with the culture-nature dichotomy and considering both the humanities and medicine as biocultural practices. On the other hand, it also implies understanding that boundary work requires boundaries, and that incommensurability between various partial disciplinary perspectives can—and will—emerge (56).

The ambition at stake here listens to the holding-together outlined above. Whereas more 'additive' ways of connecting knowledge are valuable-for instance, when humanities-based research 'fill the gaps' of 'pure' medical research in order to facilitate evidence-based care-this is not what Hyginus' text indicates. Just as the relation between Jove and Tellus is symmetric and mutual (they are equally necessary for the creation of humanity and will 'hold' remain with equal sovereignty after this life), so is the relation between Cura and the two other deities: Jove and Tellus are separated from humanity in this life, and Cura is equally separated from humanity after this life. This fable cannot be intertextually connected with asymmetrical or additive relations between knowledge fields, but it is connected with a 'space for bidirectional critical interrogation'.

It is perhaps less clear how care as un-knowing speaks to larger trends in the medical humanities. It is therefore necessary to ask: how can understandings of care that emphasise withholding and un-knowing, including autotheoretical investigations that increase uncertainty, ambiguity and painful affects, inform knowledge production?

To outline a provisional response to this question, it is useful to return to Hyginus' text once again. The description of Cura's relation to humanity_Cura quoniam prima eum finxit, quamdin vixerit, cura eum possideat (Since Cura fashioned him from the start, let Cura hold him for as long as he shall live)—should also be read with attention to grammar. While the conjunction quoniam (since) introduces a causal clause in the indicative mood (finxit), followed by an adverbial clause in the indicative (vixerit), the resulting clause is in the subjunctive (possideat). Interestingly, this subjunctive inflection is the only use of the subjunctive mood in Hyginus' text.

This use of the subjunctive mood-sometimes called 'independent' usage—can have a variety of purposes. Although the 
usage in fable CCXX is iussive-in the sense that makes a permanent judgement-it is worth noting that the subjunctive mood is often associated with potentiality in classical Latin. Other common areas of usage include "questions in which the speaker or writer expresses doubt or disbelief by "thinking aloud" (deliberative), wishes that cannot or may not be fulfilled (optative), and the potentiality that something may happen or might have happened (potential)' (Palma 2012, 377). Moreover, it is worth noting that possideat is in present tense. Since the subjunctive mood lacks a future tense in Latin, the active present tense can also denote future actions. Hyginus' text, then, points towards knowing and un-knowing, and towards openness to potentiality and some degree of uncertainty.

When held together, withholding and uncertainty give a clear implication for the medical humanities as a form of academic practice: the epistemological ambitiousness in medical humanities should be supplemented with what one might call epistemological modesty. Such modesty is rooted in the specifics of care, and in the relation between complexity and synthesis. What is at stake in care research-if we take the abovementioned complexities into account-is a 'bidirectional space', and an everexpanding and exponentially multidimensional space. When medical humanities emerged, it was only a question of time before the field began to involve other humanities and social sciences disciplines than those involved in the initial phase. Similarly, the growth of critical medical humanities steadily increases the engagements with all kinds of critical research frontiers, in the social sciences as well as in the humanities. At least in an area such as studies of care-where the intimacy is so acutely palpable-it will become increasingly clear that the medical humanities will remain 'outnumbered' or 'overpowered' by the analytical complexities the field itself brings forth.

Some scholars in the critical humanities have argued that scholars should 'embrace' this kind of overpowering (Viney, Callard, and Woods 2015, 2-7). However, Hyginus' text complicates the relation between care practices (Cura), culture (Jove) and biomedicine (Tellus) regardless of such embraces. Although care holds humanity at the expense of the other forms of knowing, his holding neither implies any disregard for humanities-based nor medical knowledge. Rather, the unpacking presented in this article demonstrates how care brings forth an epistemological modesty. Only an epistemologically modest way of doing medical humanities can address the intimate and enigmatic qualities of care.

\section{DISCUSSION: SCHOLARLY AND ANALYTICAL CONTRIBUTION}

While the textual and autotheoretical analyses presented in this paper followed the suggestion from Kristeva et al-to we question 'the cultural distinction between the objectivity of (medical) science and the subjectivity of culture' (2018:55) it nevertheless ended in an emphasis on intimate withholding. This withholding - be it epistemological, theoretical or inherent in the intimate experience of holding or embracing my son away from an abyss-is relevant to the medical humanities in general. However, it is also a contribution to four more specific tendencies in the available literature.

First, the unpacking contributes to feminist care research. Beginning with the canonical work on 'a different voice' by Gilligan (1982), feminist care research has increasingly emphasised the knowledge multitude involved in care. More recent research also shows a multitude of empirical delineations. While some scholars reserve the term for face-to-face interaction, or for situations characterised by asymmetrical dependency, others do not. The investigation in this article brings forth additional multitude by combining academic disciplines that rarely interact-care research, linguistic analysis of Latin texts, romanticism studies and autotheoretical analysis work-and implies many possibilities for further research.

Second, the autotheoretical interpretations can contribute to the research field sometimes known as ethics of care. Following such works as the book Learning from my Daughter by Kittay Kittay (2019, xx), where she proposes that the relation of parental care provides 'the only universal and morally significant property that all humans possess', I aim to shed light on how care work engenders ethical thinking. My holding of my son in my arms-as well as the withholding that both this holding and Hyginus' text entail-is as political and ethical as it is personal and embodied.

Third, this paper also relates to a more critical strain of ethics of care. Pettersen (2008) work, for instance, demonstrates how the ethics of care 'subverts the public/private dimension altogether', thereby allowing for a broader range of criticism (45). Moreover, Fletcher and Piemonte (2017) shed light on how healthcare practices constitute a 'quiet subversion' of neoliberal cultural structures. Arguably, both intimate withholding and epistemological overwhelming shows the power involved in such subversions.

Fourth, I hope to contribute to the strand of research-in care research as well as in disability studies-that relate to the work of Julia Kristeva. On the one hand, the rethinking presented in this paper dovetails with her perspectives on how intimate aspects of care destabilise the larger frameworks, cultural structures that are nevertheless sustained by those actions of care. The autotheoretical exploration towards the emblematic formulation eum possideam quamdiu vixero (I shall hold him for as long as I shall live) might also respond fruitfully to Kristeva's account of how her "living with [...] the neurological difficulties of my son David" $(2013,220)$ lead her to explore maternity as I want that you be $(2013,229)$. On the other hand, I also try to challenge what I see as an epistemological and political optimism in Kristeva's work.

Acknowledgements I would like to thank Eivind Engebretsen and John Ødemark for their encouragements, and the anonymous reviewers for their helpful suggestions.

Funding The authors have not declared a specific grant for this research from any funding agency in the public, commercial or not-for-profit sectors.

Competing interests None declared.

Patient and public involvement Patients and/or the public were involved in the design, or conduct, or reporting, or dissemination plans of this research. Refer to the Methods section for further details.

Patient consent for publication Not required.

Ethics approval The ethical aspects have been reviewed by the research management at the Work Research Institute. See also footnote 1.

Provenance and peer review Not commissioned; externally peer reviewed.

Data availability statement No data are available. Since this is an autoethnographic investigation, primary data will not be available.

Open access This is an open access article distributed in accordance with the Creative Commons Attribution Non Commercial (CC BY-NC 4.0) license, which permits others to distribute, remix, adapt, build upon this work non-commercially, and license their derivative works on different terms, provided the original work is properly cited, appropriate credit is given, any changes made indicated, and the use is non-commercial. See: http://creativecommons.org/licenses/by-nc/4.0/.

\section{NOTES}

1. Patient and public involvement statement: although there is no public involvement in the writing of this paper, the autotheoretical approach does of course involve my 
son. This approach hinders full anonymisation, just like his way of living in this world hinders informed consent in the traditional sense. The approach also excludes the potential for full anonymisation. The consent is therefore, in consultation with his mother, given by me as his legal guardian.

\section{BIBLIOGRAPHY}

Axtell, H. L. 1907. "The Deification of Abstract Ideas in Roman Literature and Inscriptions" PhD Dissertation, University of Chicago.

Ayala, R. A. 2019. "Twenty Years of Management of Care in Chile: What We Know, What We Do Not Know, What Is yet to Come. An Analysis of Arguments." Medical Humanities 45 (3): 267-77.

Bernays, J. 1869. "Herder Und Hyginus." Rheinisches Museum Für Philologie Neue Folge 15: $158-63$.

Bowring, E. A., ed. 2015. The Poems of Goethe. New Delhi: Sagwan Press

Cilione, M., S. Marinozzi, and V. Gazzaniga. 2019. "Feet and Fertility in the Healing Temples: A Symbolic Communication System between Gods and Men." Medical Humanities 45 (no.1): 21-26.

Doane, G. H., and C. Varcoe. 2008. "Knowledge Translation in Everyday Nursing: From Evidence-Based to Inquiry-Based Practice." Advances in Nursing Science 31 (no.4): 283-95.

Dougherty, C. 2006. Prometheus. Oxford: Taylor \& Francis.

Dye, E. 2009. "Sorge in Heidegger and in Goethe's Faust." Goethe Yearbook 16 (1): 207-18.

Edgar, L. 2002. "Self-Forming Selves: Autonomy and Artistic Creativity in Goethe and Moritz." Goethe Yearbook 11 (1): 159-76.

Engebretsen, E., G. Fraas Henrichsen, and J. Ødemark. 2020. "Towards a Translational Medical Humanities: Introducing the Cultural Crossings of Care." Medical Humanities 46 (2): e2.

Engebretsen, E., K. Heggen, S. Wieringa, and T. Greenhalgh. 2016. "Uncertainty and Objectivity in Clinical Decision Making: A Clinical Case in Emergency Medicine." Medicine, Health Care, and Philosophy 19 (4): 595-603.

Engebretsen, E., T. J. Sandset, and J. Ødemark. 2017. "Expanding the Knowledge Translation Metaphor." Health Research Policy and Systems 15 (1): 19.

Fletcher, E. H., and N. M. Piemonte. 2017. "Navigating the Paradoxes of Neoliberalism: Quiet Subversion in Mentored Service-Learning for the Pre-Health Humanities." The Journal of Medical Humanities 38 (4): 397-407.

Fournier, L. 2019. "Sick Women, Sad Girls, and Selfie Theory: Autotheory as Contemporary Feminist Practice." A/b 33 (3): 643-62.

Froese, K. 2005. "Woman's Eclipse: The Silenced Feminine in Nietzche and Hedegger." Philosophy \& Social Crticism 31 (no.2): 165-84.

Gilligan, C. 1982. In a Different Voice: Psychological Thory and Women's Development. Cambridge, Massachusetts: Harvard University press.

Goethe, J. W. von. 1998. "Werke: Hamburger Ausgabe in 14 Bänden." In Gedichte Und Epen I. München: Beck.

Goold, G. P., ed. 1990. Sextus Propertius: Elegies, Loeb Classical Library. Cambridge, Massachusetts: Harvard University Press.

Groth, M. 2016. The Voice That Thinks. Heidegger Studies with a Bibiliography of English Translations 1949-2015. New York: ENI press.

Hamilton, J. T. 2013. Security: Politics, Humanity, and the Philology of Care. Princeton, New Jersey: Princeton University Press.

Heidegger, M. 1927. Sein und Zeit. Halle: M. Niemeyer Verlag. München: Langen \& Müller. Heidegger, M. 1937. Hölderlin Und Das Wesen Der Dictung. München: Langen \& Müller.
Hetrick, S. E., A. P. Bailey, K. E. Smith, A. Malla, S. Mathias, S. P. Singh, A. O'Reilly, et al. 2017. "Integrated (One-stop Shop) Youth Health Care: Best Available Evidence and Future Directions." Medical Journal of Australia 207 (S10): S5.

Kittay, E. F. 2019. Learning from My Daughter: The Value and Care of Disabled Minds. Oxford: Oxford University press.

Kleinman, A. 1995. Writing at the Margin. Discouse Between Anthropology and Medicine. Berkeley: University of California Press.

Kleinman, A., and S. van der Geest. 2009. "Care' in Health Care: Remaking the Moral World of Medicine." Medische Antropologie 21 (no. 1): 159-68.

Kristeva, J. 1980. Desire in Lanuage. New York: Columbia University Press.

Kristeva, J. 2001. Hannad ARENDT. New York: Columbia University press.

Kristeva, J. 2002. "Nous Deux" or a Short (Hi()Story of Intertextuality." Romanic Review 93: 7-13.

Kristeva, J. 2012. Hatred and Forgiveness. European Perspectives. New York: Columbia University Press.

Kristeva, J. 2013. "A Tragedy and a Dream: Disability Revisited." Irish Theological Quarterly 78 (3): 219-30.

Kristeva, J.. 2019. Passions of Our Time. New York: Columbia University Press.

Kristeva, J., M. R. Moro, J. Ødemark, and E. Engebretsen. 2018. "Cultural Crossings of Care: An Appeal to the Medical Humanities." Medical Humanities 44 (1): 55-58.

Melville, A. D., and E. J. Kenney, eds. 2009. Ovid: Metamorphoses, Oxford World's Classics. Oxford: Oxford University Press.

Ovid. 1997. Metamorphoses. Books I-V. Norman: University of Oklahoma Press.

Palma, R. B. 2012. SAT Subject Test: Latin (SAT PSAT ACT (College Admission) Prep). New York: Research \& Education Associated.

Pannese, A. 2011. "The 'I' of the Beholder: Studying the 'Self' across the Humanities and Neuroscience." Medical Humanities 37 (no.2): 115-22.

Pearl, M. B. 2018. "Theory and the Everyday." Angelaki 23 (no.1): 199-203.

Pettersen, T. 2008. Comprehending Care: Problems and Possibilities in the Etchics of Care. Lanham: Rowman \& Littlefield.

Raggio, 0. 1958. "The Myth of Prometheus: Its Survival and Metamorphoses up to the Eighteenth Century." Journal of the Warburg and Courtauld Institutes 21 (1/2): 44.

Schillace, B. 2017. "New Way of Seeing." Medical Humanities 43 (no.3): 139-40.

Schott, G. D. 2017. "Whence 'Zoster'? The Convoluted Classical Origins of a Sometimes Illogical Term." Medical Humanities 43 (no. 1): 15-18.

Smith, R. S., and S. Trzaskoma, eds. 2007. Apollodorus' Library and Hyginus' Fabulae: Two Handbooks of Greek Mythology. Indianapolis: Hackett Publishing Company.

Stahl, D., and D. G. Stahl. 2016. "Seeing Illness in Art and Medicine: A Patient and Printmaker Collaboration." Medical Humanities 42 (no.3): 155-59.

Viney, W., F. Callard, and A. Woods. 2015. "Critical Medical Humanities: Embracing Entanglement, Taking Risks." Medical Humanities 41 (no. 1): 2-7.

von Herder, JG. 1888. Herders Sämmtliche Werke. Vol XIII. Berlin: Weidmannische Buchhandlung.

von Herder, JG. 1889. Herders Poetische Werke. Edited by Carl Redlich. Berlin: Weidmannische Buchhandlung.

Wieringa, S., E. Engebretsen, K. Heggen, and T. Greenhalgh. 2017. "Has Evidence-Based Medicine Ever Been Modern? A Latour-Inspired Understanding of a Changing EBM." Journal of Evaluation in Clinical Practice 23 (no.5): 964-70.

Winthrop, R. 2003. "Reflections on Working in Post-Conflict Afghanistan: Local versus International Perspectives on Gender Relations." Women's Studies Quarterly 31 (3/4): 247-52.

Nelson, M. 2015. The Argonuauts. Minneapolis: Graywolf press. 